\title{
State-in-Society: the Mutual \\ Constitutiveness of the Developmental State and Higher Education in South Africa
}

\author{
Beverly Thaver \\ Faculty of Education, University of the Western Cape \\ Email:bthaver@uwc.ac.za \\ and \\ Lionel Thaver \\ Department of Anthropology and Sociology, \\ University of the Western Cape \\ Email:lthaver@uwc.ac.za
}

\begin{abstract}
Seeking to go beyond the pessimism and reification of contemporary analyses of the state in Africa, this article applies Migdal's State in Society (2001) approach to the field of higher education transformation in South Africa. It argues that the state is best understood through its actual practices, particularly at those points where it reaches into society through policy implementation and, conversely, where society through its institutions in turn reaches into the state. In the course of these engagements, social boundaries are constituted through alliances, accommodations and resistances and have a mutually transformative effect on both state and society. The article shows how, with regard to both the image and the practices of the state, the relationship between the developmental state and higher education in South Africa reveals a range of tensions around issues such as accountability, autonomy, transformation and globalisation; and it concludes that Migdal's approach offers a fruitful theoretical corrective to state-centric and socio-centric views of the state-society relationship.
\end{abstract}

Key Words: Developmental state, South Africa, globalisation, higher education

\section{Introduction}

Contemporary analyses of the state in Africa have tended to adopt a rather pessimistic view of its role in modernisation and development. Among the varied explanations offered for the weakness of states in Africa are the ongoing effects of colonial territorial divisions, economic underdevelopment, bureaucratic 
inefficiency, ethnic diversity and traditional patrimonialism. Leaving aside the undoubted relevance of such explanations in themselves, what many of these analyses have in common is that they present the state-society relationship as a bifurcated one. Even though they tell us something significant about the state, or the market, civil society, bureaucracy, ethnicity or traditional authority, this is achieved at the expense of reifying these particular units of analysis. By contrast, the following analysis of the state-society relationship, as exemplified in the relationship between higher education in South Africa and the state, aims to side-step the debate over what might be the 'royal road' to understanding modernity in Africa, and instead is premised on the idea that the best way to understand the state and its conditions of possibility rests in the state's actual practices. In so doing, we do not discount the role of state/society theory but rather focus precisely on those moments when the state reaches into society through policy implementation and, conversely, where society through its institutions in turn reaches into the state, government and administration. This latter approach to the state-society relationship on the basis of the mutual engagements of its constituent elements draws upon Migdal's (2001) state-in-society framework, a model which not only offers a way of focusing on the level of social practices but also has the virtue of simplicity.

The article proceeds in five parts. It begins by identifying substantive aspects of Migdal's state-in-society framework in order to provide the conceptual lens for a state-in-higher education inquiry. Following this, it explores, in an introductory way, what Migdal calls the dialectic between the image and the practices of the state, particularly as these pertain to the developmental state in South Africa. On the basis of this theoretical (state-in-society) and empirical (the South African developmental state) grounding, the article proceeds to probe aspects of the state's engagement with higher education institutions, and addresses policy tensions as these relate, first, to the image, and second, to the practices, of the developmental state. The final section focuses on higher education and the national developmental project.

\section{The State-in-Society Framework}

The rich and diverse international literature on the state is characterised by a range of competing theoretical perspectives, including Marxist (of both instrumentalist (Miliband, 1973, 1983) and structuralist (Poulantzas, 1973, 1978; Therborn, 1978, 1986) varieties), liberal (Dahl, 1971), Weberian (Skocpol, 1979; Evans et al, 1985) and poststructuralist (Foucault, 1991; Bourdieu, 1994) approaches. This richness and diversity of the debates especially in terms of the 
relationship between capitalism and the apartheid state is also reflected in the South African literature across the liberal (Lipton, 1986) and radical (Wolpe, 1972, 1988; Legassick, 1974; Davies et al, 1976; Alexander 1979, 2002) divide. We refer the reader here to an insightful analysis of the debates by Motala (2006). In much of this literature there tends to be a bi-polar focus on the issue of state autonomy versus social autonomy, with either one or the other taking precedence (Hobson, 2001). For example, both neo-Marxists like Miliband (1973) and liberal pluralists like Dahl (1971) favour the latter, stressing the weakness of civil society and of the working class, or the weak market sector, respectively; while statists like Skocpol (1979) stress the former. Apart from a concern with this polarised feature of the state debate, what prompted the writing of this article was a reading of Migdal's (2001) work on how states and societies constitute one another. In contrast to views which set the state and society off against each other, Migdal's state-in-society approach is premised on the principle of the mutually transformative nature of relations between state and society.

The two key concepts in his approach devolve to the image and the actual practices of the state in a process of mutual engagement. Whereas the image of the state pertains to a perceptual process that revolves largely around a cultural formation, the practices of the state refer to the engagement of its apparatuses in society, raising the question of the social boundaries that exist between the state and society. To this end we ask; what, then, are the dynamics of the social engagement between the state and society?

In reconceptualising the relationship between state and society, Migdal (2001:231) suggests that conventional theories of the state often concern themselves with the problem of obedience, including the sorts of structures and cultures that might facilitate it. In so doing, they tend to focus on the structural apparatuses of the modern state (such as parliaments, bureaucracies and judicial systems), and in varying degrees tend to reproduce the "analytic isolation of the state [which] has led to a mystification of its capabilities and power" (Migdal, 2001:232). However, in situ the modern state's putative sovereign and external positioning above society is paradoxically a condition that is likely to be tempered, even weakened, by the state's engagement with other social groups. In thus seeking to "understand how the state's sails have been trimmed through its engagement with such social forces", Migdal (2001:250) shifts the relationship between state and society from a problem of structure to one of process. In contrast to conventional theories, his conception of the modern state tries to capture the dynamics of the state within itself (that is, intra-state, in terms of its multiple parts) and within society (that is, in terms of the drawing and redrawing of social boundaries) as these occur in actual practice. 


\section{Image and practices as elements of the state}

What emerges with regard to Migdal's understanding of the image of the state is that it is perceived in the main as the "dominant and single centre of society"; one that is "autonomous, unified and centralized" (Ibid: 16-17). This image of an omnipotent state radiating throughout society is prone to mystification, especially when conflated with its reality (that is, its practices), which by contrast often appear 'limited', 'divided' and 'constrained'. The perception of the state as a 'dominant and single centre' not only separates state from society (that is, from non-state actors and social forces) but also elevates it above society. In addition by representing 'the people' or the general interest, the state seemingly marks itself off from other social forces that represent particular interests. However, in 'real politick' the state is immersed in vested interests of all kinds testifying to its location in society rather than 'being' outside or above as implied in dualistic constructions thereof whether considered from the bottom up or top down. While the latter is necessarily the case at the level of practices it is the image which concerns us in terms of how it coheres at the level of perception, that is as a belief system.

Migdal (2001: 237) drawing on the field of cultural studies illustrates by way of example how the norms, values and assumptions (that is, culture) that supposedly cohere and enable the state to move and reinforce itself as a 'single centre', in fact has 'centrifugal tendencies'. What is significant here with implications for higher education in particular and the institutional milieu in general is that in reality the normative consensus is strained such that the centre is pulled in different directions. With this in mind Clifford Geertz's (1973) study of the early Balinese state (cited in Migdal, 2001:238) is used to show how certain cultural practices in that state surfaced a tension between the "integrative effects of the state provided by the controlling political ideal and the disintegrative effects of the power system composed of a myriad of sub-rulers." What is important to note here is that it is within the context of contradictory forces that a political culture (e.g. constitution) is marshaled to galvanise the state's image and in so doing prevent a crisis of credibility or legitimacy and hence institutional chaos or anomie. This element of the image of the state is therefore concerned with the ideological "mortar that binds the bricks of the state together" into a coherent whole, or in other words, the ideas, beliefs and values that unify the state (Migdal, 2001:239).

On the other hand, the element of the practices of the state has to do with the routine performance of the state's actors and agencies as these seek to implement the policies of the state's political projects inside society. In the actual daily practices of the bureaucracy and administration, the state's image could be either bolstered, neutralised or weakened (Migdal, 2001:18). Alongside practices such 
as the implementation of policies, there are also other state practices, such as ceremonies and inauguration rituals that serve to "reinforce and validate the social separation between the state and other social actors"(ibid). It is particularly important to consider "those practices - the routinized performative acts that go against the grain of a coherent, unified and controlling state" (ibid:19), because such practices may also contradict or challenge the unified and coherent image and thereby weaken the social divide.

It is at this latter level that the mutually transformative nature of state-insociety becomes a crucial site for understanding the state/society dialectic. The question of how these social boundaries are manifested in the dynamic of statein-society engagements is addressed through the political imperatives of the formation of coalitions, alliances, accommodations and zones of opposition and resistance that occur within these mutual engagements.

What we are arguing is that Migdal's framework enables one to obtain a better understanding of the relationship between the state and society as a field of power in which there is a de-distanciation between these two entities (hence state-in-society) and thus a mutual transformation is potentiated. This does not mean that the state and society are not distinguishable from each other but rather that as separate entities they come into contact with each other through their mutual engagements and the logic of their articulation.

What is thus presupposed as far as we are able to discern is that a spatial politick is involved which is taken up by Migdal in his notion of the drawing of social boundaries. This negotiation of boundaries lies at the core of the relationship between the state and higher education institutions as case in point which we will take up later. However, before this we turn to the matter of social boundaries and its relation to the image and practices of the state.

\section{Image and practices in the drawing of social boundaries}

Migdal's concept of social boundaries is a means of establishing the formative zones in which relationships between the state and society are redrawn and reconstituted. These boundaries, which occur through the practices of the state as it engages in coalitions, alliances, accommodation and resistance with other social forces, are contingent insofar as state practices may serve either to reinforce, or to contradict and neutralise, the image of the state, and thus shore up or undercut the perception of the state as a unified centre of absolute authority. For Migdal (2001:19),

while the image of the state implies a singular morality, one standard way of doing things, practices denote multiple types of performance and possibly some contention over what is the right way to act.

In effect, the differences registered in practices across the spectrum of the 
state might be more than mere deviations from what the state defines as its normative framework. Expressed positively, such deviations from the norm could be understood as counter hegemonic practices, which are not accidental and incidental but are instead practices which are self-sustaining in that they firm up as social regularities.

Migdal's approach thus brings to bear a cultural orientation that takes account of so-called 'deviant' behaviours that ultimately serve as contestations over the drawing and redrawing of social boundaries between the state and society, as a function of the public (duty) and private (accumulation) divide. However, at the level of what happens within the state and its various agencies (through government, bureaucracy and administration), an additional dimension can be observed, one that operates intra-institutionally, that is, within the state and its organs. For instance, similar boundaries emerge as a function of the hierarchical structure of the state and its agencies, where the process of drawing and redrawing boundaries operates as a function of the distribution of power within the state and is also subject to the logic of the building of coalitions, alliances, accommodations and resistances. Thus, Migdal's emphasis on the notion of social boundaries yields a theoretical opportunity for a re-specification of the state/society relationship. With this in mind, we move on to probe the dialectic of image and practices as these pertain to the developmental state in South Africa.

\section{The Developmental State in South Africa}

It is not the intention of this article to delve into the meaning of a developmental state, short of stating that it is oriented around a developmental ideology at the level of the economy and seeks to foster growth and technological modernisation (Mkandawire, 2001; Woo-Cummings, 1999; Castells, 2000; for aspects of the nascent debate in South Africa, see Edigheji, 2006, 2007; Desai and Bond, 2006; Southall, 2006 and especially Motala, 2006, and Motala and Pampallis, 2007, whose suggestion that understanding the developmental path in South Africa requires an engagement with broader state theory helped prompt the writing of this article). Our particular purpose is to examine how the tensions between the developmental state's image and its practices unfold in its efforts to contribute to the national normative project via the restructuring of higher education institutions.

\section{The image of the developmental state}

In terms of the image of the state as a 'dominant and single centre of society' 
(Migdal, 2001:16-17), of relevance here are those ideas, beliefs, values and norms which contribute to the perception of the developmental state as a unified centre. With respect to the developmental state in South Africa, the element of the image and how it functions as a social Gestalt depends heavily on how it has been conceived and articulated by that political party which governs the state and enjoys overwhelming popular support, namely, the African National Congress (ANC), and how it seeks to project unity in the face of apparent differences between itself and its alliance partners. In foregrounding the ANC in the discussion on the image and practices of the state we are mindful that the impression is created that we are conflating the ruling party with the state. We would like to make our position categorically clear that we do not equate the ruling party with the state complex but risk this conflation to make the point that the state is in fact fractured along a number of lines one of which is at the level of the political party vis-à-vis other contesting parties. With this caveat in place we take up the matter of the tripartite alliance as an example of the fault lines that cut across the state as a manifestation of the mutual constitutiveness of the state-in-society. And secondly we raise this example to serve as an exemplar for the relationship between higher education institutions and the state in as much as it reflects the differential positions they have in relation to each other and the different purchase they make on each other.

The ANC's developmental normative framework (ANC, 1998) highlights four principles: an improvement in the quality of life; equity; justice; and economic growth. Taken together, these principles reflect the development task as being both material and ideational, the former being addressed particularly in economic growth and the latter in equity and justice. Thus, the overarching vision is a composite view of development expressed in terms of creating the general conditions necessary for improvements in the quality of life. As such it presents a condition of possibility for the perception of the state as a unified whole. However, in relation to the ANC's practices with its alliance partners, the image of the state is both reinforced and neutralised. One partner, the Congress of South African Trade Unions (COSATU), is fairly specific in terms of what it seeks from the developmental state, namely, a state that can drive development in ways not restricted to, and even in opposition to, the free market approach currently seen to be in favour (COSATU, 2005). In this respect the perceived unity of the state in as much as it involves the ruling bloc seems to be contradicted by one of its alliance partners. Similarly, the approach to development of the other alliance partner, the South African Communist Party (SACP), includes ideas such as 'responding to market failure, identifying the state's function as the provider of essential services, creating the conditions to achieve developmentoriented growth and promoting redistribution' (SACP, 1998). In this regard, 
the state's perceived image viewed through the ruling party's power structure is both reinforced and neutralised insofar as it relates to the politics of its alliance partners.

With regard to the specific approaches by the alliance partners to the four principles of the normative framework, on the one hand the image of the state is reinforced in those instances involving agreement across the elements of equity, justice and improvement of the quality of life. On the other hand, with respect to economic growth as the Archimedean lever of social development, the divergent position of labour as represented, consistently in terms of its sectoral interest, by COSATU, neutralises the image of the state as an absolute authority standing above society. In the case of the SACP, the image of the state is reinforced to the extent to which it concurs with the general will of the state in terms of the provision of services and a regulatory framework informed by a developmental orientation. However, the SACP, too, is not persuaded by a market driven approach, although it recognises in the developmental state the social responsibility to assuage the structural effects of the logic of capital. It follows that the ANC's relationship to its alliance partners is contradictory and thus we might infer that the image of the state as far as it is mediated through the ruling party is continually being constituted and reconstituted in said engagements with social forces contending for hegemony around social policy. This example clearly shows that the state is engaged in drawing and redrawing boundaries within the ambit of its own structure as a ruling power bloc but more importantly since the state is in society this does not stop at this intra level of engagement, it radiates throughout the institutional milieu and finds its way, as we will show later, into higher education institutions as well, as case in point.

\section{The practices of the developmental state}

With regard to the element of the image of the state, and despite contestations over the content of this image, the state nevertheless projects itself as a unified field and is received as such by civil society. Notwithstanding this, the practices of the state are in themselves heterodox, and as such the coherence and unity of the state is not entirely palpable at this level. It is important to note that these practices are not merely instrumental or technical mechanisms but are tied to the image of the state in ways that reinforce, neutralise or undermine its standing in society. In this regard, the disjuncture between policy formulation and policy implementation, in particular delivery is a salient example of how the state is undermined in terms of its standing for those communities adversely affected. In this process, the alliances and coalitions between the state and social actors subsequently impact on their respective social boundaries and as such distinguish and set up the practices in terms of a mutually transformative dynamic (Migdal, 
2001).Here, we make reference to the tripartite alliance as outlined earlier in which, what is evidenced are the kinds of contestatations and tensions alluded to in establishing their respective social and political boundaries between them.

In his analysis of the developmental state, Edigheji also arrives at the mutually transformative nature of alliance formation as described by Migdal, but from a different vantage point by using the concept of social embeddedness (Edigheji, 2007; see also Evans, 1995). He argues that alliance formation "requires high levels of coherence on the part of state agencies - it has to behave as a coherent collective actor capable of identifying and implementing developmental goals and should not be overwhelmed by particularistic interest groups" (Edigheji, 2007:8).

While Edigheji's analysis shows how the image comes to bear on the practices of the state insofar as it seeks to constitute itself as a 'coherent collective actor' that transcends sectoral interests, it does not consider practices to be multivariate (as Migdal does), and thus does not address the fragmentary and divisive effects of the state's practical engagements in society.

\section{The State-in-Higher Education: Policy Tensions in Relation to the Image of the State}

We turn now to an analysis of the mutually constitutive relationship between the state and higher education as a function of the relationship between the image and practices of the developmental state, and probe how this unfolds in the efforts to transform higher education institutions. The past decade has been marked by much policy activity on the part of the state as well as the implementation thereof in higher education institutions (CHE, 2004). In the engagement of the developmental state with that of higher education institutions and vice versa, and in the state's efforts to redress the legacy of fragmentation, what kinds of normative tensions arise?

\section{Normative tensions in relation to image}

The developmental image of the state and its normative framework are manifested in the higher education arena in the form of an insistence on a single, unified and nationally coordinated system, operating under the auspices of the principles of equity, redress, democratisation, development, quality, effectiveness, efficiency, academic freedom, institutional autonomy and public accountability (Department of Education, 1997:11-13; CHE, 2004).

On the one hand, from the state's angle, institutions have to account for how these elements of the normative framework will be developed in their respective 
constituencies. Here, the image of the state is projected as the national centre from which the developmental project radiates. Nevertheless, while Minister Pandor, depicts a close relationship between the state and the university, and brings the universities into the purview of the state's national project (Pandor, 2005:3), the executive arm of the state has tended to argue for a more clearly demarcated boundary between itself and that of the epistemic project of the universities (Mbeki, cited in Pandor, 2005). There are thus normative tensions with regard to the role and function of universities within different apparatuses of the state. On the other hand, the view from the university is that, given the central role that higher education plays in terms of human resource development, universities need to be invested with trust and confidence, with due cognisance being accorded to the state's requirement for universities to "self-regulate and be publicly accountable" (Pityana, cited in Pandor, 2005). When one considers the university as an institution in terms of its own stated image, that is, in its relation to society as a whole, there is a convergence between Pityana's and Pandor's understanding of that relationship. But there remains a potential tension between the way that the state engages with a university and how this engagement re-shapes its image in the public eye. There is a multidirectional (state-university-society) process at work when one considers the state in situ. That is, the image of the state appears to be restricted to its actual practices, which reins in the otherwise potentially unlimited projection of its image; but at the same time, it appears that the university's own image as an autonomous institution is circumscribed by actual practice, in the form of what is described as 'conditional autonomy' and 'cooperative governance'.

\section{The policy process and policy implementation: the limits of the state in situ}

One of the challenges of the post-1994 developmental period is the translation of policy objectives into practice. The conventional view of the policy development and implementation process is that it is unilinear and sequential (CHE, 2004), (as if the state simply imposes its policy on society), but this view is belied by "the enormous complexity of large-scale transformative policy change" in South African higher education, with the policy development process itself being "complex and multilayered" and with several policies being formulated and implemented at the same time as several structural changes (CHE, 2004:36).

Among scholars and policy makers alike there is a perception that, during the late 1990s, a hiatus emerged between policy formulation and policy implementation (CHE, 2004). What is more important for the analysis being developed here, however, are the reasons for or implications of this hiatus. As the National Plan for Higher Education suggests, 
the implementation vacuum has given rise to a number of significant developments, including unintended and unanticipated consequences which, if left unchecked, threaten the development of a single coordinated but diverse higher education system (Department of Education, 2001:8).

The division between the image and the practices of the state are apparent in the reference, in the same breath, to a 'single coordinated' system which is nevertheless 'diverse'. Aside from the implementation vacuum itself, the existence of unintended and unanticipated consequences give a sense of the limited nature of the state in situ, and implies that one is not dealing with a unified centre that directs change. In turn this calls into question both the model of the state as elevated and standing outside society, and the corresponding political strategy of seeking a cataclysmic reckoning with the state. Instead, it lends support to Migdal's model of the state in society (and society in the state) and suggests a politics of critical engagement with the state on a terrain replete with relatively greater potential for transformation.

Furthermore, and together with the acknowledged complexity of policy development and implementation processes, it evokes an image of state practices as multi-linear and simultaneous yet also diverse and discrete, and of a state that is dispersed (in terms of multiple alliances and accommodations) and labyrinthine (as being mutually interlocking in itself and in relation to society). To some extent, this means that conflict becomes institutionalised, in as much as one works with and through the state and its agencies or at its points of interface with other social forces, given that social projects (such as the epistemic project in the case of the university) are not exhausted by the political projects of the developmental state but forever begin anew (for example, in negotiations around the redrawing of social boundaries). Nevertheless, there can be no question that the state-in-society model domesticates conflict, for conflict is always implicit, and often emerges explicitly, in the kinds of alliances, accommodations, oppositions and resistances that occur (for example, in the case of higher education, around policy implementation).

\section{The policy process and symbolism}

Another common perception among scholars (though not among policy makers) is that the initial stages of higher education policy formulation in South Africa were largely symbolic, being primarily concerned with declaring a break with the past (Jansen, 2001; Cloete et al,2002). This view fails to distinguish sufficiently between symbolic policy formulation and substantial political transformation, or between whether a real break is seen to take place and engaged with in institutional life and whether this break occurs only at an abstract or 
perhaps normative level. In reality there is no such thing as a clean break with the past: political projects (in this case, the developmental project in higher education) inevitably come up against a status quo that, to a greater or lesser extent, resists efforts to transform it, but where Migdal's approach proves useful is that it pays attention to the degree to which a new normative framework establishes a particular kind of relationship to the past, and not only a clean break as such.Instead of wishing away the past, the state in society approach focuses on the modalities of actual practices. Thus, to return to the question of symbolism, it would be better to say that the policy formulation phase marked the pomp of the state as developmental, democratic and constitutional. To the extent to which this was symbolic, it was a symbolism which was more about affirming the present than denying the past. As Migdal shows, drawing on Geertz's (1973) study of the early Balinese 'theatre state' (cited in Migdal, 2001:238), the symbolism of the state as an expression of its pomp is not a means to extend the state's power; rather, the state's power serves the end of the state's pomp. In other words, what, in the South African case, is rendered 'pompous', is the state's new democratic content, and what needs further investigation is how the symbolism attached to the plethora of policy formulation in the first phase of the democratic dispensation can be viewed as an ideological reckoning with the past which is predicated on the power connoted in the image of the state.

\section{The State-in-Higher Education: Policy Tensions in Relation to the Practices of the State}

\section{Autonomy and accountability: delimiting the boundaries of the institutional domain}

Despite, but perhaps indirectly because of, the gap between policy formulation and policy implementation, one of the central tensions arising from state efforts to effect its policies is the universities' perception of the state as being strongly interventionist. On the one hand, universities in terms of their general role in society express agreement with the state's normative framework and thus are seen to accommodate the national developmental logic. However, this logic exacerbates tensions between the university's (unified) image of itself as a national public institution and its (unified) image as an autonomous institution (see Jansen, 2004, Du Toit, 2007, and Waghid et al, 2005). On the other hand, with regard to the (unified) image of the state and how it views the social position of the university and its academic project, there is a tension between how the university fulfills its role within this developmental normative framework and the state's function in overseeing and intervening insofar as it seeks to fulfill 
its political mandate. In each of these instances, the practices of the state and the practices of the university with respect to questions of accountability and autonomy provide fertile soil for the kinds of contestations that mutually inform each other's development under contemporary conditions. Whether the university sees the state's intervention on a particular issue as hostile or adversarial, or whether it sees this issue as a matter for historical redress, hinges (in part, but not entirely) on the relatively privileged position that such a university might have enjoyed in the past. On the flipside of autonomy is the thorny question of the public accountability of the universities. While state practices in this regard may be suggestive of sanctions, in that they involve the state's coercive capacity to induce obedience to and conformity with its policies, rules and procedures, they may also be no more than a reflection of the modern state imperative to standardise and universalise practices within the prescriptions and proscriptions of a national normative framework.

In reality, what takes on additional meaning is that the uneven institutional topography (that is, the legacy of apartheid) is itself the social imperative behind practices intended to renegotiate and redraw social boundaries. These practices are accompanied by contradictory and neutralising processes as well as opposition and resistance. It is by honing in on state-society relations in their mutual engagements of coalitions, alliances and accommodations, that one is better able to understand how the state, its agencies and society mutually constitute each other. This process of mutual constitutiveness of state and society takes one to the heart of the developmental project in South Africa, namely, those practices that inform the renewal of the social infrastructure.

\section{State coordination: cooperation, cooptation and resistance}

A key feature of a developmental state is the need to coordinate the different parts of the overall system in order to ensure coherent policy formulation and implementation (Edigheji, 2007). In higher education, this process is facilitated by a coordinating body - the Council on Higher Education (CHE) - that brings together the various practices in relation to the overall national developmental project, and interfaces between the universities and the state. From a statecentric perspective, the working relationships thus developed through the mutual engagement of the $\mathrm{CHE}$, the state and the universities, might be considered to be equivalent to state cooptation (Waghid et al, 2005), but this is only a foregone conclusion if one adopts a zero-sum conception of power. From a state-in-society perspective, these relationships involve boundary crossings and the emergence and firming up not only of alliances and accommodations but also of resistances amongst special interest groups; for this perspective takes its cue from a more pastoral conception of power. Were a form of cooptation to 
indeed emerge out of the state-university interface, this is more likely to be a result of a successful manufacture of consent by state practices.

The state-in-society approach also pays close attention to the social relations and institutional forms that emerge in the multidirectional engagements of state, public institutions and society. Overlaps between the coordinating structures of the state (in terms of state officials) and the coordinating structures of the university (in terms of executive-level management) give an indication of how social boundaries are being drawn and redrawn, and these in turn are mutually transformative of both the state and university. The $\mathrm{CHE}$, for example, in its efforts to coordinate the state-university relationship and ensure continuity and stability within the system, has spearheaded several annual consultative fora and engaged with specific interest groups. The National Working Group established to oversee the higher education restructuring process included groups representative of both business and higher education, and this created the conditions for an 'efficiency and effectiveness' discourse to increase its influence on higher education practices. Despite the fact that the state canvasses for a broad consensus on matters influencing public policy, efforts to maintain continuity and avoid major disruptions may also have the effect of being conservative and reformist in orientation and thereby fall short of substantive transformation.

\section{Accountability, academic freedom and curriculum reform: cooperation and resistance}

The realisation of the national developmental project requires the leveling out of the historically uneven field of higher education, and this pertains especially to the standardisation of curriculum practices. The impetus for such large scale curriculum reform, emanating initially from labour, was spearheaded by the state in the form of the National Qualifications Framework (NQF).

In the course of this process the social boundaries between the state and the university began, to some extent, to blur, not least because matters of equity and social justice are as dear to the state's unified normative framework as they are to the universities' pedagogic project. Mutually constituting each other, the universities to varying degrees have to recalibrate their institutional practices to conform to the preferred modalities of the state, while in its turn the state's curriculum-standardising intervention acts directly upon, and in so doing implicates itself in, the practices of teaching and learning at universities.

However, the real import of the NQF as a bureaucratic intervention vis-à-vis its potential for initiating pedagogic reflexivity remains in question.

Following the requirements of the NQF, academics proceeded to identify different kinds of modules (fundamental, core, elective) ... with little 
consideration of the curriculum implications of such physical division of disciplinary knowledge. .... What preoccupied institutional planners and academic planners and academic departments, was the largely bureaucratic and organisational task of preparing their qualifications for purposes of interim registration with the South African Qualifications' Authority (Jansen et al, 2007:166).

Thus, even though the normative framework underpinning the NQF was largely agreed to by universities, the actual process of its implementation was influenced by a range of factors, including the universities' self-image of academic freedom and autonomous regulation. Here again we come up against the limited nature of the state, and the mutual constitutiveness of state apparatuses and social institutions. This example also highlights another clash between the image and the practices of both the state and the universities vis-à-vis the NQF, specifically between the university's image of itself as an autonomous institution and the state's image of itself as effecting public accountability. As the state seeks to redraw social boundaries in relation to curriculum reform in the universities, the universities resist by establishing zones of alternate meanings that involve a re-specification of academic 'freedom' in ways that are caught up in their own institutional practices.

It follows from this that, rather than seeking analytically to understand the nature and impact of the state by juxtaposing its practices against its normative framework, it would be more fruitful to show how practices unfold in the mutually transformative engagement of the university and the state, and how the image of the state with respect to its developmental normative framework, which underpins its project of curriculum reform, is either aligned or at odds with the university's need to accommodate the state's preferred modality for representation (as per the NQF), and with the university's practices that end up effecting the evacuation of the epistemic project.

\section{The State-in-Higher Education and the National Developmental Project}

\section{Coalitions, alliances, accommodations and interest groupings}

A key facet of the state's efforts to advance the image of a unified normative framework for higher education has been the establishment of a structure which can 'speak with one voice for the sector' (CHE, 2004). The historically fragmented nature of higher education in South Africa is apparent in the various organisations that until recently managed the sector, such as the South 
African Vice-Chancellors Association, the Council of Technikon Principals and the Association of Vice-Chancellors of Historically Disadvantaged Tertiary Institutions in South Africa.In the unfolding of the post-1994 policy environment an alliance has been formed between the executive levels of the universities and the state, an alliance firmed up by the institutional accommodation of the state by the universities in what is now called Higher Education South Africa.

To this extent, the state is seen to be inside institutions and institutions are seen to be inside the state.

The social boundaries between the state and society are thus effectively being redrawn; insofar as universities are increasingly adopting corporatist and managerialist forms of governance; and insofar as the state is increasingly incorporating the epistemic markers of the knowledge society, and the information revolution by engaging academics as consultants and policy advisers, and deploying them under the auspices of the Higher Education Quality Council, to review the content of academic programmes.

\section{The limited state and the limited university: public accountability, economic growth and global forces}

In terms of the national development framework, universities in South Africa are obliged to promote human resource development, an undertaking which requires extensive capital investment even as the current global tendency is towards reduced public expenditure on higher education and cost reductions, even while trying to expand enrolment in higher education (Menon et al , 2006).

Using the GDP index in SA, the state's higher education budget has declined by almost 23\% in six years (Menon et al, 2006:3), and the concomitant increase in university tuition fees is certainly not in favour of the poor. This trend is likely to compromise the image of the state as serving the public good, and reduce the degree of trust and legitimacy invested in the state.

It follows that any investigation of the post-1994 developmental state has to factor in these and other constraining effects of the neo-liberal global context. Social policies predicated on market fundamentalism will inevitably come into conflict with the developmental framework and especially with efforts to redress class, race and gender inequalities. In this regard, through its accommodations with global forces such as the International Monetary Fund and the World Bank, the state-in-the-global-context reveals itself as a 'regulatory' and a 'facilitative' state (Carmody, 2002), even while continuing to foster an image of itself as a developmental state. Thus the image of the state also varies in relation to its specific engagements with society in general (national, continental and global), and this suggests that the state in relation to its practices is at 
once limited, constrained, divided and fragmented.

\section{Conclusion}

Migdal's state-in-society model with its dialectic of images and practices offers a fruitful theoretical corrective to state-centric and socio-centric views of the state-society relationship, in that its attention to praxis restores equivalence to both state and society, thereby freeing them from reification. However, the extent to which the state-in-society model hones in on the actual practices involved in the mutual engagements of the state and society, it pays less attention to the bigger theoretical picture, and thus would benefit substantially from the stock of theoretical knowledge available in the state-centric and socio-centric views. This notwithstanding, it can be concluded that, on the basis of the exploratory state-in-society analytical approach developed here, the state can be understood as a structure in the process of becoming, and not merely in the way it ought to be. In other words, the state is informed and altered by the relationships established when other social forces engage with the state and vice versa. These relational effects, and the mutual constitution of state and society along a developmental trajectory, reveals the South African state to be a limited state with limited capacity (but nonetheless with real effects), rather than an omnipresent and omnipotent social force with unbounded capacity. In the process of describing some of the mutually transformative and constitutive alliances, accommodations and resistances that have arisen in the context of the engagement of the state with the higher education sector, the dynamism of the state in drawing and redrawing social boundaries has become apparent and, in particular, it has been shown that these boundaries are mediated not only by the state and its apparatuses but also by the higher education institutions with which they are engaged. Moreover, these boundaries delimit a number of tensions between the (ostensibly unified albeit multiple and contradictory) image of the state and its (fragmented and apparently unsuccessful yet not ineffective) practices, caught up as they are in the ebb and flow of local, national, supranational and global social contingencies.

\section{Postscript}

With the advent of the new political dispensation under the leadership of President Zuma (2009) and the reconfiguration of the Ministry of Education into higher and basic, with the former under the leadership of Minister Nzimande, certain subtle changes can be noted. Whereas President Mbeki was explicit 
about the demarcation of the state and higher education and thus foregrounded the role of the executive, President Zuma, on the other hand, appears to defer to the Ministry of Higher Education and in so doing plays down the executive arm. The opposite is true when we consider Ministers Pandor in relation to Nzimande. What Ms Pandor seemed to have alluded to with respect to the relationship of higher education to the national project, Dr Nzimande makes explicit. The former dealt more with the image of the state, in other words, the focus seemed to fall more on policy with a 'hands off' approach to universities.

By contrast Minister Nzimande appears to be closer to an engaged state in as much as he seeks to be developing a new regimen of practices that in effect takes the state through him into higher education with what appears to be hedging towards a 'hands on' approach thus recasting the boundaries between the two. Having signaled certain potentialities in the current dispensation it must, however, be qualified by pointing out that it is clearly still too soon to tell which way the political current will flow: whether towards greater integration of the state in society, that is a de-distanciation between state and society.

Or whether a putative duality of state and society will be maintained where the distance between the two is such that it reinforces the myth of the 'ivory tower' carrying with it social reification and social sterility. Thus the challenge to higher education institutions following on Migdals state-in-society' approach espouses a level of social engagement without epistemic compromise, which sees instead universities-in-society: that is, a praxis standing neither above nor outside society, and moreover, is not an image of itself bordering on a simulacrum.

\section{Acknowledgements}

We thank Enver Motala for his probing and analytical insights on matters concerning state theory; Frinde Maher for the micro-level reach of the state in higher education and John McDermott for drawing our attention to global practices in pertaining to states as well as the distinctions between state, government and administration. Their invaluable comments helped tighten the argument and overall structure of the paper, however, we take full responsibility for the views expressed in the paper.

Enver Motala, Research Coordinator, Education Policy Consortium, Centre for Education Policy Development.

Frinde Maher, professor emeritus, Wheaton College and Brandeis Centre for Research on Women, USA.

John McDermott, professor emeritus, SUNY, Editorial Board of the Review of 
Radical Political Economics, USA.

\section{References}

ANC (1998) The State, Property Relations and Social Transformation. African

National Congress. http://www.anc.org.za/ancdocs/pubs/umrabulo/ articles/sprst.html. Accessed 2 January 2009.

Bourdieu, P. (1994) Re-thinking the State: Genesis and Structure of the Bureaucratic Field. Sociological Theory, 12, 1: 1-18.

Carmody, P. (2002) Between Globalisation and Post Apartheid: The Political Economy of Restructuring in South Africa. Journal of Southern African Studies, 28, 2: 255-275.

Castells, M. (2000) End of Millennium. Cambridge, MA: Blackwell.

CHE (2004) South African Higher Education in the First Decade of Democracy.

Pretoria: Council on Higher Education.

CHE (2007) Review of Higher Education in South Africa: Selected Themes.

Pretoria: Council on Higher Education.

Cloete, N., Fehnel, R., Maasen, P., Moja, T., Perold, H. and Gibbon, T. (2002)

Transformation in Higher Education: Global Pressures and Local Realities in South Africa. Cape Town: Juta.

COSATU (2005) A developmental state for South Africa. Congress of South African Trade Unions. http://www.cosatu.org.za/cc2005/ Developmental.pdf. Accessed 2 January 2009.

Dahl, R. A. (1971) Polyarchy. New Haven, CT: Yale University Press.

Davies, R, Kaplan, D, Morris, M, O’Meara, D, (1976) Class Struggle and the

Periodisation of the State in South Africa, Review of African Political Economy, Vol 7.

Department of Education (1997) Education White Paper, No. 3: A Programme for the Transformation of Higher Education. Government Gazette.

Pretoria: Department of Education.

Department of Education (2001) National Plan for Higher Education. Pretoria:

Department of Education.

Desai, A. and Bond, P. (2006) Crony Neoliberalism and Paranoid Nationalism: Debating South Africa's 'Developmental State', University of KwaZuluNatal Press, Pietermaritzburg.

Du Toit, A. (2007) Autonomy as a Social Compact. Pretoria: Council on Higher Education.

Edigheji, O. (2006) The Discourse of the Developmental State and a People's Contract in South Africa. Policy: Issues and Actors, Vol 19 No. 5. 
http://www.cps.org.za/cps\%20pdf/pia19_5.pdf

Edigheji, O. (2007) The Emerging South African Developmental State. Research Report No. 108, Centre for Policy Analysis, Gauteng. http://www.cps. org.za/cps\%20pdf/RR108.pdf.

Evans, P. (1995) Embedded Autonomy: States and Industrial Transformation. Princeton: Princeton University Press.

Evans, P., Rueschemeyer, D. and Skocpol, T. (1985) (eds) Bringing the State Back In. Cambridge: Cambridge University Press.

Fataar, A. (2003) Higher Education Policy Discourse in South Africa: A Struggle for Alignment with Macro-Development Policy. South African Journal of Higher Education, 17, 2: 31-39.

Foucault, M. (1991) Governmentality, in Burchell, G., Gordon, C. and Miller, P. (eds) The Foucault Effect: Studies in Governmentality. Chicago: Chicago University Press.

Hobson, J. M. (2001) The 'Second State Debate' in International Relations: Theory Turned Upside Down. Review of International Studies, 27: 395-414.

Jansen, J. (2001) Rethinking Education Policy Making in South Africa: Symbols of Change, Signals of Conflict, in Kraak, A. and Young, M. (eds) Education in Retrospect: Policy and Implementation since 1990. Pretoria: Human Sciences Research Council.

Jansen, J. (2004) Accounting for Autonomy. The $41^{\text {st }}$ TB Davie Memorial Lecture, University of Cape Town, 26 August.

Jansen, J., with Herman, C., Matentjie, T., Morake, R., Pillay, V., Sehoole, C. and Weber, E. (2007) Tracing and Explaining Change in Higher Education: The South African Case, in Review of Higher Education in South Africa: Selected Themes. Pretoria: Council on Higher Education.

Legassick, M. (1974) Legislation, Ideology and Economy in Post-1948 South Africa, Journal of Southern African Studies, Vol 1 (1).

Legassick, M. (1974) Capital Accumulation and Violence, Economy and Society, Vol. 2 (3)

Lipton, M. (1986) Capitalism and Apartheid: South Africa, 1910-1986, Wildwood House.United Kingdom.

Menon, K., Cele, N., \& Bhengu, T. (2006) Value for Money and Quality in Higher Education. Paper presented to Symposium on Quality in Higher Education, University of Stellenbosch.

Migdal,J.S. (2001) State in Society: Studying how States and Societies constitute one another. Cambridge: Cambridge University Press.

Miliband, R. (1973) The State in Capitalist Society. London: Quartet Books. Miliband, R. (1983) Class Power and State Power. London: Verso. 
Mkandawire, T. (2001) Thinking about Developmental States in Africa. Cambridge Journal of Economics, 25: 289-313.

Motala, E. (2006) 'State Analysis': Its Importance to Theory, Critique and Practice: The Case of the Apartheid State. Unpublished paper, prepared for the Democracy, Human Rights and Social Justice Programme of the Education Policy Consortium: The State Analysis Project. Johannesburg.

Motala, E. and Pampallis, J. (2007) Education and the State: Some Reflections on the Education Policy Consortium's Research, in Malcolm, C., Motala, E., Motala, S., Moyo, G., Pampallis, J. and Thaver, B. (eds) Democracy, Human Rights and Social Justice in Education. Johannesburg: Centre for Education Policy Development.

Pandor, N. (2005) African Universities and the Challenges of a Developmental State. D.C.S. Oosthuizen Memorial Lecture delivered by the South African Minister of Education, Rhodes University, Grahamstown, 15 August.

Poulantzas, N. (1973) Political Power and Social Classes. New York: Verso.

Poulantzas, N. (1978) State, Power, Socialism. New York: Verso.

SACP (1998) The African Communist, 149. http://www.sacp.org.za/main. php?include=pubs/acommunist/1998/Issue149.HTML. Accessed 2 January 2009.

Skocpol, T. (1979) States and Social Revolutions. New York: Cambridge University Press.

Southall, R. (2006) Introduction: Can South Africa be a Developmental State?, in S. Buhlungu (et al.), State of the Nation - South Africa 2005-2006, Cape Town

Therborn, G. (1978) What does the Ruling Class do when it Rules? New York: Prometheus Books.

Therborn, G. (1986) Karl Marx Returning: The Welfare State and Neo-Marxist, Corporatist and Statist Theories. International Political Science Review, 7, 2: 131-164.

Waghid, Y., Berkhout, S., Taylor, D, and De Klerk, J. (2005) In Defence of Institutional Autonomy and Academic Freedom: Contesting State Regulation of Higher Education. South African Journal of Higher Education, 19, 6: 1177-1195.

Wolpe H.1972, Capitalism and Cheap Labour Power in South Africa: From Segregation to Apartheid, Economy and Society, Vol. 1(4).

Wolpe, H. 1988, Race, Class and the Apartheid State, London, James Currey. Woo-Cummings., 1999, The Developmental State, Cornell University Press, New York 